\title{
The impact of Accounting Information Systems (AIS) on performance measures: empirical evidence in Spanish SMEs ${ }^{1}$
}

Elena Urquía Grande. Complutense University of Madrid. Spain. eurquiag@ ccee.ucm.es

Raquel Pérez Estébanez. Complutense University of Madrid. Spain. raquel.perez@ccee.ucm.es

Clara Muñoz Colomina. Complutense University of Madrid. Spain. cimunnoz@ccee.ucm.es

\begin{abstract}
This research study is aimed, based on empirical evidence, at measuring the relationship between the use of the Accounting Information Systems (AIS) by the Small and Medium Sized Enterprises (SMEs) in Spain, and firms' improved performance indicators and productivity. This empirical study is based on a survey carried out among small and medium-sized firms to ascertain the extent to which development and implementation of accounting information systems had taken place, and subsequently an analysis was made as to how much this introduction may impact on improvement in outcome indicators and productivity. As interesting results we have found that there is a positive relationship among the SMEs that use AIS for fiscal and bank management and better performance measures. This research provides value added in accounting literature given the scarcity of works dealing with the relationship between the application and use of AIS and performance and productivity indicators in SMEs in Spain.
\end{abstract}

Keywords: Accounting Information Systems (AIS), Small and Medium-Sized Enterprises (SMEs), performance measures, productivity.

\footnotetext{
${ }^{1}$ We would like to thank Professor Carlos Rivero, from the Statistics Department (UCM), for his valuable assessment. Also we would like to thank the anonymous reviewers of the journal for their contributions.
} 


\section{INTRODUCTION}

Accounting Information Systems (AIS) are a tool which, when incorporated into the field of Information and Technology systems (IT), were designed to help in the management and control of topics related to firms' economic-financial area. But the stunning advance in technology has opened up the possibility of generating and using accounting information from a strategic viewpoint. Since this is important for all firms, it is more important even for medium-sized and small ones which need this information to deal with a higher degree of uncertainty in the competitive market (El Louadi, 1998). Thus, they need to improve their systems and data processing capacity to match their information needs (Van de Ven and Drazin, 1985). Investing in staff training, improving the quality of products and internal processes and increasing AIS investment will be the leverage for achieving a stronger, more flexible corporate culture to face continual changes in the environment. Innovation is the incentive with which a virtuous circle will be put in place, leading to better firm performance and a reduction in the financial and organizational obstacles, while making it possible to access capital markets.

In order to deploy these strategies, Spanish firms have needed to invest in technology to promote information and communication in different areas of the organization such as production, design, innovation, marketing, commercial management or after sales service, because all of them are very directly identified with gaining or losing market share. This, in turn, has to be reflected in the results and productivity achieved. Although in comparative organizational cultures among countries Spain appears as a country with high resistance to changes that deliver uncertainty such as companies' investments in IT (Hofstede, 2001). Still, in the last years Spanish companies have developed significantly above all on the tertiary sector and have made great efforts to reorganize and innovate (Banegas and Myro, 2008). Currently in Spain, in the majority of areas, there is a common understanding that using information technologies has been crucial to broaden markets and to spare selling management costs. In Spain information society and the new computer tools have allowed the companies to make a better use of their accounting systems in their relations with suppliers and customers. In the same way the development of the electronic banking allows the companies to save a lot of time in their transactions; moreover AIS have fastened tax management. 
On the other hand, to what extent this investment in specific technology for the economic-financial area is related to performance and productivity indicators is a question as yet insufficiently analyzed. Studies have been made by many authors regarding the potential IT contribution, in general, to increasing SME productivity. The latter, even in moments of crisis such as the present time, opt for the need to continue investing in this type of technology to achieve continuous company improvement (Cramm, 2008).

As information and communications technologies cover a wide range and include all the areas in which a firm acts, this research work has focused on a specific part of them, the accounting information systems (AIS) to show that computerized accounting tools are directly related to the economic and financial results and productivity in small and medium-sized business organizations. AIS are systems used to record the financial transactions of a business or organization. This system combines the methodologies, controls and accounting techniques with the technology of the IT industry: user interface, computers and sophisticated software. The software used to track transactions provides internal reporting data, external reporting data, financial statements, and trend analysis capabilities.

The research work has focused on SMEs because these firms in Spain account for more than $90 \%$ of the country's business (Central Companies Directory, 2010). An optimal implementation of AIS by SMEs means adapting more successfully to a changing environment and shows a high degree of competitiveness, thus enhancing the dynamic character of a company (even when a company is small, it must assimilate the use of AIS). In other words, there are improvements in administrative management regarding accountancy and finance. By using AIS, it is possible to gauge the risk of some operations or predict future earnings with sophisticated statistical software applications. All these benefits have been developed and tested in larger companies and it should be possible to extend them to SMEs.

Nevertheless, it has also been pointed out that the challenges of successful development in the information society lay not so much in the availability of good technological infrastructure as in improving business disposition toward AIS use (Scapens and Jazayeri, 2003; Scapens, et al., 1998). Thus, and in accordance with several authors, it is of great interest to analyze the impact of AIS on economic and financial profitability indicators (Return On Assets (ROA) and Return On Equity (ROE)) and the productivity of small and medium-sized Spanish firms.

The results obtained in this research work suggest that there is a direct relationship 
between using AIS for fiscal and bank management and performance indicators and it reveals how important it is to implement them in such firms; however, there is no evidence of the relationship between AIS use and productivity.

The structure of this article is as follows: first, a review of the bibliographic state of the art in this issue has been done, where the research questions are designed. After the empirical methodology is described and the ANOVA statistics applied; finally results discussion is made and main conclusions drawn.

\section{STATE OF THE ART}

The main advantages of an optimal use of AIS in SMEs are: better adaptation to a changing environment, better management of arm's length transactions and a high degree of competitiveness. There is also a boost to the dynamic nature of firms with a greater flow of information between different staff levels and the possibility of new business on the network and improved external relationships for the firm, mainly with foreign customers accessed through the firm's web. With the existence of more intercommunication there are increased chances for diversification of traditional businesses. Nonetheless, excessive use of these tools may decouple the quality of interaction between workers and customers with a consequent reduction in productivity. Therefore, there are authors who defend the need for a profound change in firms' organizational culture to make these installations productive (Asaro, 2000; Gallivan and Srite, 2005; McGrath, 2006; Nicolau and Bhattacharya, 2006).

\subsection{AIS and performance measures}

Existing literature offers scant evidence of the relationship between these AIS and performance measures; though it is important to highlight the study made by Ismail and King (2005) which discovered a positive association between AIS alignment and SME strategy and performance measures. In the Spanish case, Naranjo-Gil (2004) posits an indirect relationship between AIS and firms' performance via the varying strategies that may be adopted by companies. Thanks to investment in AIS, the scope for action is expanded, thus providing time saving in trips to and dealings with banks, the Administration, etc. This reduces firms' costs. Productivity increases when these innovations are properly used. Insofar as a firm's culture is open to the introduction of new accounting information systems 
this will lead to a more holistic view of it and make for greater flexibility and dynamism in organizational search for improved results.

Despite of some authors who postulate that the direction of the cause-effect relationship is only that companies achieve a high performance when they can afford the implementation of certain technological developments (Damanpour and Gopalakrishnan, 2001). Others indicate that firm performance drops just after the implementation, taking several years to realize the benefits from IT adoptions (Wah, 2000). There are several research works, which, in the widest sense, have studied relationships between performance indicators and IT, and how IT impact on firm performance achieving inconclusive results.

There are studies which obtain a positive relationship between investment in IT and economic profitability, financial profitability and value added (Menachemi et al., 2006; Huang and Liu, 2005; Ravichandran and Lertwongsatien, 2005; Verhees and Meulenberg, 2004; Brynjolfsson and Hitt, 2003; Santhanam and Hartono, 2003; Bharawadj, 2000; Li and Ye, 1999; Powell and Dent-Micallef, 1997; Barua et al., 1995; Dos Santos and Peffers, 1995). Other research shows that no clear relationship exists between this type of investment and the performance indicators. (Dibrell et al., 2008; Bharadwaj, et al., 1999; Rai et al., 1996). Their authors argue that, currently, IT are readily available and using them gives no competitive advantage for achieving improved results (Powell and DentMicallef, 1997).

Similarly, they maintain that many firms have invested in IT but they do not succeed in attaining the established performance goals. Although research on the IT-performance ratio is more abundant in large-sized firms, the analysis of the impact on smaller-sized ones becomes particularly important because investment in these technologies may give them a competitive advantage and the chance to position themselves to achieve better results since they are more flexible and have better response capability (Pérez et al., 2010; Tanabe and Watanbe, 2005; Izushi, 2003; Larsen and Lomi, 2002).

In Spain, in most sectors, there is a generalized opinion that using information technologies has been decisive in expanding the business market and in saving commercial management costs. Given that AIS are a basic component derived 
from technologies in general, the main issue is whether applying accounting information systems contributes to firms' improving their results. For this reason, and in view of the scarcity of studies on the subject, this article focuses on analyzing whether there is any relationship between economic and financial profitability and how much AIS are used in bank and fiscal management in Spanish SMEs.

In view of the state of affairs the following research question is defined:

RQ1: Do Spanish SMEs which use AIS have better economic and financial performance indicators?

\subsection{AIS and productivity}

Once the literature had been reviewed, there is a dearth of articles researching on the relationship between AIS and productivity. When the search was extended to publications relating productivity and IT, many studies support the theory that their proper use increased firms' productivity and, thus, had a decisive influence upon wealth and growth in a country (Hitt and Brynjolfsson, 1996; LópezSánchez, 2004; Dozier and Chang, 2006).

Nevertheless there is a wide range of publications on the relationship between IT and productivity. There are studies that analyse the IT impact on company's productivity and obtain results that have led to the so- called "productivity paradox" (Brynjolfsson and Hitt, 1996; Hitt and Brynjolfsson, 1996). This hypothesis states that firms adopting IT innovations do not seem to experiment significant increases in their financial performance, as productivity gains are translated into benefits to customers. However, non-adopting firms may suffer from productivity decreases due to the competition from their IT-adopting counterparts.

According to the OECD (OECD, 2000) countries which invest the most in these technologies are also leaders in productivity growth. However, in the case of Spain, though the role of IT in business productivity is proven, the SME Report 2008 (Maroto, 2008) published by the Industry Minister on supply and use of information technologies in Spanish SMEs confirms the low performance in this factor. In recent years, the value and evolution of productivity has been lower than 
that in the rest of the main economies (Maroto et al. 2008). Recently, Santamaría et al. (2010) have demonstrated that IT implementation derived in a decrease of labour time and therefore a decrease in costs and Badescu and Garcés-Ayerbe (2009) have analyzed the impact of investments in IT on the productivity of Spanish firms and have found that although the firms in the sample experienced some improvement in productivity in the considered period, this improvement was not significantly derived from IT investment. In view of that the following research question is defined:

RQ 2: Do Spanish firms which use AIS have higher productivity?

\section{EMPIRICAL STUDY}

This empirical study is based on a survey carried out among small and medium-sized firms to ascertain the extent to which development and implementation of accounting information systems had taken place. Subsequently an analysis was made as to how much this introduction may impact on improvement in outcome indicators and productivity. Once the survey had been prepared it was revised and validated at the conceptual level, by a group of experts in the subject and compared by having personal interviews with seven managers belonging to sample firms. In this way we chose the most important questions for our analysis. Later on, a selected sample was sent to SMEs, obtained from the SABI database, and bearing in mind size, operating profit, asset volume and how demanding the revealing of financial information was, following the definition of national SMEs (Maroto, 2008; Milanés, 2007; Nieto and Fernández, 2006), and international (Duc Son et al., 2006). Also taken into account were the legal status, incorporating only those with the highest presence in the business area, the date when the firm was established, with the most recent being chosen, as well as asset volume and operating income, plus a favourable auditor's report regarding the rating for the accounts. Specifically the criteria for choosing firms were:

- Number of employees: minimum; 10; maximum 250

- Legal status: Joint Stock Company, Private Limited Company

- Date of establishment: after $1 / 1 / 2000$ 
- Total assets (thousand Euros); maximum 12,320,000 euros

- Operating income (thousand Euros) maximum 24,640,000 euros

- Auditor's opinion; Audited accounts approved

With these criteria a sample of six hundred and thirty two firms was obtained and the survey was carried out. A valid rate of response of $12.5 \%$ was achieved (of which five were eliminated because of errors in the replies, leaving a total of seventy four valid replies). A deeper study was made of the firms which had replied, following criteria of the European Union based on number of employees:

- From 10 to 49 employees: small firms

- From 50 to 249 employees: medium-sized firms

In the sample of firms replying to the questionnaire $96 \%$ were medium-sized and $4 \%$ small. In graph 1 the values of the sample are revealed with regard to number of employees, income and total assets.

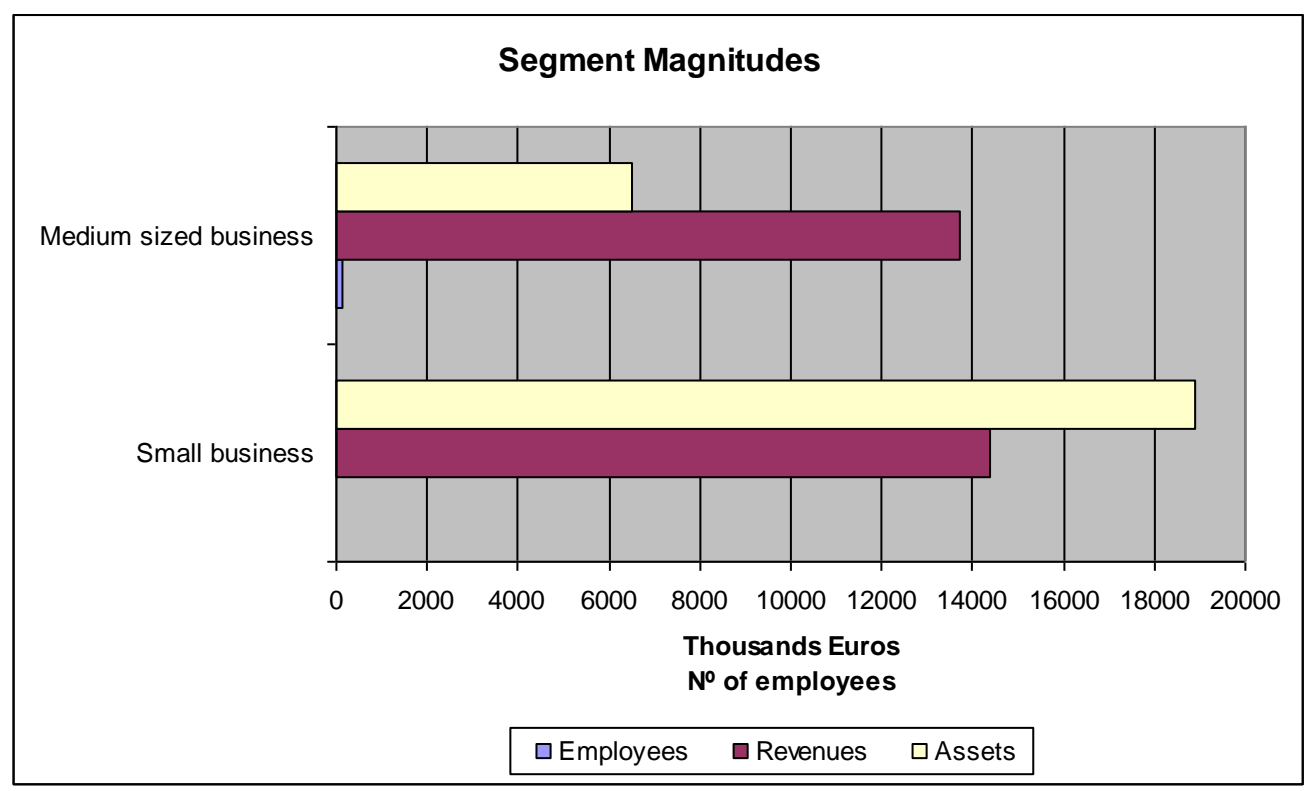

Graph 1. Classification of firms according to EU criteria. Source: authors 
Moreover, an analysis of the results by sectors of activity shows that $34 \%$ of the SMEs belonged to the industrial sector, $55 \%$ to the service sector, $8 \%$ to the construction sector and $3 \%$ to the primary sector, and the average number of years which the company has been operating is 10 .

It is necessary to highlight that three indicators have been chosen to study the effects of the degree to which computerized accounting systems have been set up. These indicators are productivity, economic and financial return in accordance with the studies of Brynjolfsson and Hitt, 2003; Bharadwaj ,2000; Tam, 1998; Rai et al., 1996 for the ROA and ROE and of Dozier and Chang, 2006; LópezSánchez, 2004; Black and Lynch, 2001 for productivity.

The definitions of the ratios used in accordance with the database used (SABI) are as follows: ROA (corresponding to the initials of the Anglo-Saxon term "Return on Assets" is calculated as the financial year result divided among total assets, ROE (conforming to the initials of the Anglo-Saxon term "Return on Equity") is calculated as the financial year result divided among own equity and productivity and equals operating income after deductions for Marketing, Raw Material consumption and working expenses, all of them divided by staff costs.

In the statistical analysis, in order to delve more deeply into the results the data were then segmented into four groups taking into account the possibilities of response regarding the use of AIS for bank and fiscal management.

In this way group one is composed of firms using AIS both for bank and fiscal management, group two consists of firms using AIS solely for bank management, group three embraces firms which use AIS merely for fiscal management and, finally, group four includes firms not using them either in bank or fiscal management.

In the following stage of the research an ANOVA analysis was made to compare measures among the four SME samples and examine the results. To validate the empirical study and given that there were missing data on quantitative variables (Economic Returns, Financial Profitability and Productivity) the correlations between the different quantitative variables were analyzed and the missing values treated with the maximum likelihood method and the EM 
algorithm was applied to obtain the estimator. Subsequently, the descriptive statistics of the sample have been analyzed (Table 1).

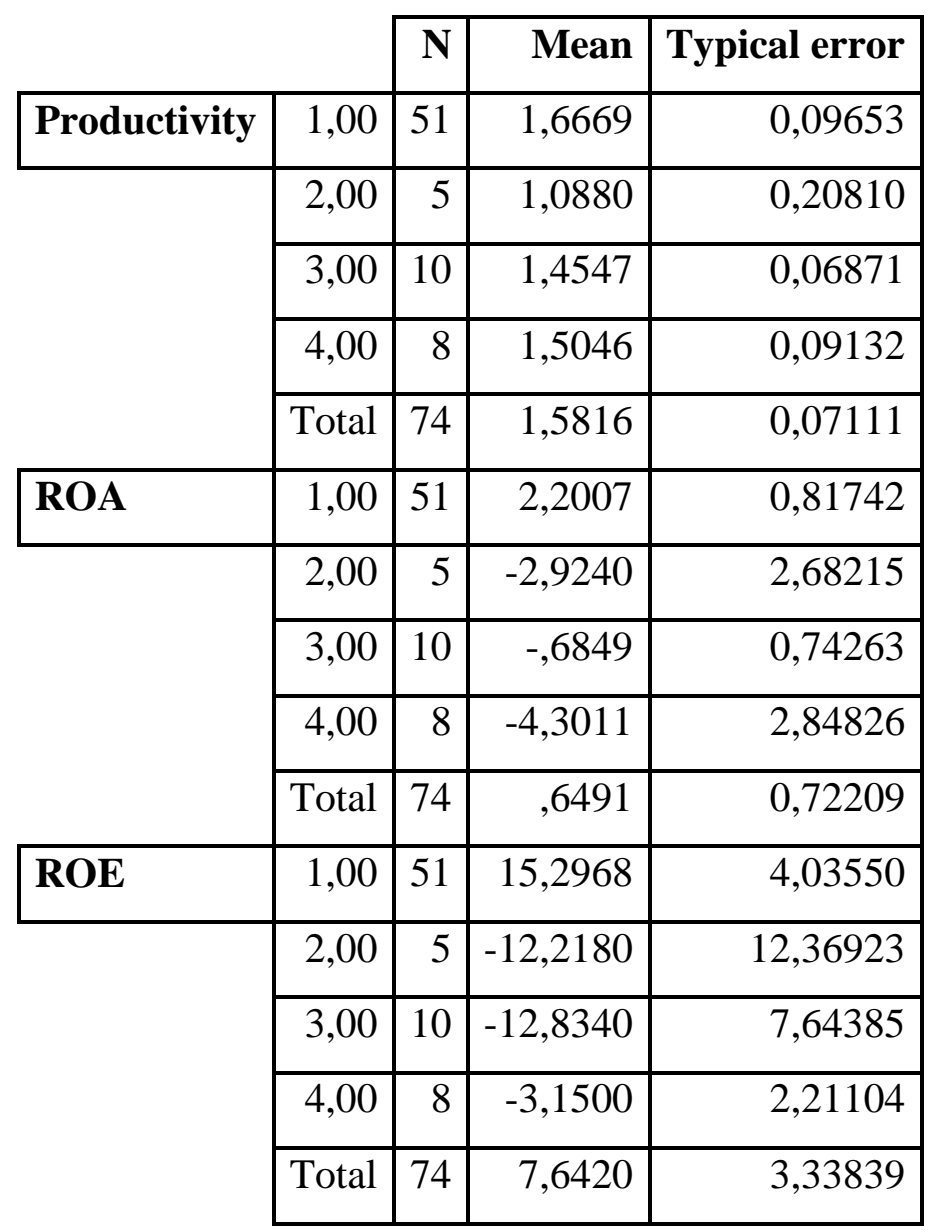

Table 1. Summary of relevant variables

In the second stage the normality of the variables has been analyzed by means of the Kolmogorov-Smirnov test. When the correctness of the normality was achieved, the next step was to make a parametric analysis of the variables by checking whether there is homocedasticity with Levene's Test between the three variables (Productivity, ROA and ROE) (Table 2). Since the principles of normality and homocedasticity were complied with in the samples studied an 
ANOVA analysis was carried out to compare the hypotheses posited.

\begin{tabular}{|l|l|l|l|}
\cline { 2 - 4 } \multicolumn{1}{c|}{} & Levene Statistic & gl1 & gl2 \\
\hline Productivity & 0,558 & 3 & 70 \\
\hline ROA & 1,370 & 3 & 70 \\
\hline ROE & 0,686 & 3 & 70 \\
\hline Significant at 95\% & \multicolumn{3}{|l}{} \\
\hline
\end{tabular}

Table 2. Variance Homogeneity test

\section{RESULTS}

The results are statistically significant for the ROA and ROE performance indicators but not so for productivity (Table 3).

\begin{tabular}{|l|r|}
\cline { 2 - 2 } \multicolumn{1}{c|}{} & F \\
\hline Productivity & 1,644 \\
\hline ROA & $3,964 *$ \\
\hline ROE & $4,695 * *$ \\
\hline **Significant at 99\% *Significant at 95\% \\
\hline
\end{tabular}

The first research question suggested that in the case of those SMEs which use AIS for their bank and fiscal management there was a significant relationship with the performance indicators. On the basis of the results it is indeed shown that not only is there such a relationship, it is also a positive one because there is a significant difference in the measures between groups one and four in the ROA and between groups one and three regarding the ROE (Table 4). With regard to economic returns this implies that those SMEs using AIS for bank and fiscal management have higher profitability than those not using it, the group 1 average is 2.20 and group 4 has -4.30 . With regard to financial returns, the same situation occurs but the significance is established between groups 1 and 3 . The group 1 
average is 15.29 , against 12.83 for group 3 and it even becomes negative for firms in group 4.

The second research question posed the idea that those SMEs that used AIS for bank and fiscal management had a significant relationship with productivity. Bearing in mind the results obtained it is seen that the difference in intergroup measures is not significant, so it can be said to be a matter of indifference in productivity terms whether firms use AIS for their bank and fiscal management or not (Table 4).

\begin{tabular}{|c|c|c|c|c|}
\hline Dependant variable & (I) IT & (J) IT & $\begin{array}{l}\text { Difference of averages } \\
\text { (I-J) }\end{array}$ & Typical error \\
\hline \multirow[t]{3}{*}{ Productivity } & 1,00 & 2,00 & ,57894 & ,28294 \\
\hline & & 3,00 & ,21226 & ,20881 \\
\hline & & 4,00 &, 16234 & ,22960 \\
\hline \multirow[t]{3}{*}{ ROA } & 1,00 & 2,00 & 5,12469 & 2,71620 \\
\hline & & 3,00 & 2,88557 & 2,00455 \\
\hline & & 4,00 & $6,50179 *$ & 2,20411 \\
\hline \multirow[t]{4}{*}{ ROE } & 1,00 & 2,00 & 27,51482 & 12,53947 \\
\hline & & 3,00 & $28,13082 *$ & 9,25412 \\
\hline & & 4,00 & 18,44682 & 10,17539 \\
\hline & & \multicolumn{3}{|c|}{$*$ Significant at $95 \%$} \\
\hline
\end{tabular}

Table 4. Multiple comparisons (Bonferroni)

\section{DISCUSSION OF RESULTS AND CONCLUSIONS}

Considering the average returns the results indicate that firms which use AIS for the whole of their management obtain a higher, more positive figure with regard to the other groups of firms which show a negative average. This means that the effort made by SMEs to implement, invest and improve their AIS is related to their economic and financial results, since firms not using AIS or only 
partly using it obtain losses. Similarly, if we go more deeply into an analysis of financial returns, this has been higher among those firms using AIS globally compared to firms just using them for fiscal management. This proves that the latter are wasting resources provided by AIS.

Even though we state that a greater effort in using AIS corresponds to better financial and economic results; in line with the contingency theory, we are aware that in the results obtained other complementary variables are combined as an alignment with organizational culture and company's long-term strategy. In other words, a well-defined strategy in favor of investing in AIS and favoring their use needs an organizational culture to accompany it, even if in the short- term allocating resources to AIS may lessen performance and this factor in times of crisis may act as an entry barrier for making investments in this type of technology. Consequently, it is necessary to analyze the correlation between investments in AIS and certain changes in firms' productive organization (especially greater decentralization in the work process, a change to more favorable relationships with customers and suppliers and an increase in the number of skilled workers joining the firm).

Regarding the relationship between a firm's productivity and the use of AIS, results show that there is no significant relationship. The explanation for these results may lie in the fact that productivity is a more complex concept than the one using the SABI database-focusing on staff costs- although productivity could be analyzed from its three components: efficiency, technological change and change of scale, which has not been part of this study.

A limitation of this work is the ratio of response from SMEs and the fact that most of them are medium sized rather than small. This could mean sample bias. Future research trends of this work are to carry out an analysis on the regression between the performance indicators and productivity and the use of AIS by introducing the time variable. Likewise, we plan to prepare a survey of a more qualitative nature geared to managers to relate investment in AIS, strategy and long-term performance indicators.

Finally, this research provides value added for practitioners and academics in accounting given the scarcity of works dealing with the relationship between the 
application and use of AIS and performance and productivity indicators in SMEs in Spain. This opens up the possibility of further studies on this topic.

\section{REFERENCES}

ASARO, P. M. (2000): "Transforming society by transforming technology: the science and politics of participatory design", Accounting Management and Information Technologies, vol. 10: 257-290. http://dx.doi.org/10.1016/S0959-8022(00)00004-7

BADESCU, M.; GARCÉS-AYERBE, C. (2009): "The impact of information technologies on firm productivity: Empirical evidence from Spain", Technovation, vol. 29: 122-129. http://dx.doi.org/10.1016/j.technovation.2008.07.005

BANEGAS, J.; MYRO, R. (2008): Impacto de las Tecnologías de la Información en la Economía Española, Thomson Civitas, Navarra, Spain.

BARUA, A.; KRIEBEL, C.H.; MUKHOPADHYAY, T. (1995): "Information technology and business value: An analytical and empirical investigation", Information System Research, vol. 6, n. 1: 3-23. http://dx.doi.org/10.1287/isre.6.1.3

BHARADWAJ, A.S. (2000): “A resource-based perspective on Information Technology Capability and Firm Performance: An empirical Investigation”, MIS Quarterly, vol. 24: 169-196. http://dx.doi.org/10.2307/3250983

BHARADWAJ, A.S.; BHARADWAJ, S.G.; KONSYNSKI, B.R. (1999): "Information Technology effects on Firm Performance as measured by Tobin's q", Management Science, vol. 45, n. 7: 1008-1024. http://dx.doi.org/10.1287/mnsc.45.7.1008

BLACK, S.E.; LYNCH, L.M. (2001): "How to compete: the impact of workplace practices and information technology on productivity", Review of Economics and Statistics, vol. 83, n. 3: 434-445. http://dx.doi.org/10.1162/00346530152480081

BRYNJOLFSSON, E.; HITT, L. (1996): "Paradox lost? Firm level evidence on the returns to information systems spending, Management Science, vol. 42, n. 4: 541-558.

BRYNJOLFSSON, E.; HITT, L. (2003): “Computing productivity: Firm-level evidence”, The Review of Economics and Statistics, vol. 85, n. 4: 793-808. http://dx.doi.org/10.116 $\underline{2 / 003465303772815736}$

CRAMM, S. (2008): "Smaller IT Budget? Pursue Value Driven development", Harvard Business Review-Voices, November 20. 
CENTRAL COMPANIES DIRECTORY. Instituto Nacional de Estadística http://bit.ly/gs2o81 (October 2010).

DAMANPOUR, F.; GOPALAKRISHNAN, S. (2001): "The dynamics of the adoption of product and process innovations in organizations", Journal of Management Studies, vol. 38, n.1, pp. 45-65. http://dx.doi.org/10.1111/1467-6486.00227

DIBRELL, C.; DAVIS, P.S.; CRAIG, J. (2008): "Fueling innovation through Information Technology in SMEs", Journal of Small Business Management, vol. 46, n. 2: 203-218. http://dx.doi.org/10.1111/j.1540-627X.2008.00240.X

DOS SANTOS, B.; PEFFERS, K. (1995): "Rewards to investors in innovative information technology applications-First movers and early followers in ATMs", Organization Science, vol. 6, n. 3: 241-259. http://dx.doi.org/10.1287/orsc.6.3.241

DOZIER, K.; CHANG, D. (2006): "The effect of company size on the productivity impact of Information Technology Investments", Journal of Information Technology Theory and Application, vol. 8, n. 1: 33-47.

DUC SON, D.; MARRIOTT, N.; MARRIOTT, P. (2006): "User's perceptions and uses of financial reports of small and medium companies (SMC) in transitional economies: Qualitative evidence from Vietnam", Qualitative Research in Accounting and Management, vol. 3: 218-235. http://dx.doi.org/10.1108/11766090610705416

EL LOUADI, M. (1998): “The relationship among organisation structure, information technology and information processing in small Canadian firms", Canadian Journal of Administrative Science, vol. 15, n. 2: 99-180.

GALLIVAN, M.; SRITE, M. (2005), "Information Technology and culture: Identifying fragmentary and holistic perspectives of culture", Information and Organization, vol. 15: 295-338. http://dx.doi.org/10.1016/j.infoandorg.2005.02.005

HITT, L.; BRYNJOLFSSON, E. (1996): "Productivity, business profitability, and consumer surplus: three different measures of information technology value", MIS Quarterly, vol. 20, n. 2: 12-142. http://dx.doi.org/1 $\underline{0.2307 / 249475}$

HOFSTEDE, G. (2001): Culture's Consequences: Comparing Values, Behaviors, Institutions, and Organizations across Nations, 2nd Edition. Thousand Oaks, CA: Sage Publications. 
HUANG, C.J.; LIU, C.J. (2005): "Exploration for the relationship between Innovation, IT and Performance", Journal of Intellectual Capital, vol. 6, n. 2: 237-252.http://dx.doi.or $\mathrm{g} / 10.1108 / 14691930510592825$

ISMAIL, N.A.; KING, M. (2005): "Firm performance and AIS alignment in Malaysian SME's", International Journal of Accounting Information Systems, vol. 6, n.4: 241-259. http://dx.doi.org/10.1016/j.accinf.2005.09.001

IZUSHI, H. (2003): "Impact of the length of relationships upon the use of Research Institutes by SMEs", Research Policy, vol. 32, n. 5: 771-788. PII: S0048-7333(02)00085-9

LARSEN, E., LOMI, A. (2002): "Representing change: a system model of organisational inertia and capabilities as dynamic accumulation processes", Simulation Modelling: Practice and theory, vol. 10, n.5-7: 271-296. PII: S15 6 9-1 9 0X(0 2 )0 008 5- 0

LI, M., YE, L.R. (1999): "Information technology and firm performance: Linking with environmental, strategic and managerial contexts", Information and Management, vol. 35, n. 1: 43-51. PII: S-0378-7206(98)00075-5

LÓPEZ SÁNCHEZ, J.I. (2004). “¿Pueden las Tecnologías de la información mejorar la productividad?", Universia Business Review, January-March: 82-95.

MAROTO J. A. (2008): "Las PYME españolas con forma societaria”, Ministerio de Industria, Turismo y Comercio, Madrid.

MCGRATH, K. (2006): "Affection not affliction: The role of emotions in information systems and organizational change", Information and Organization, vol. 16: 277-303. http://dx.doi.org/10.1016/j.infoandorg.2006.09.001

MENACHEMI, N.; BURKHARDT, J.; SCHEWCHUK, R.; BURKE, D.; BROOKS, R.G. (2006): "Hospital Information Technology and positive financial performance: a different approach to finding ROI”, Journal of Healthcare Management, vol. 51, n. 1: 40-59.

MILANÉS, P. (2007), "Propuesta de una definición de PYME con fines contables", CISS Técnica Contable, vol. 59, n 694: 31-39.

NARANJO-GIL, D. (2004): “The Role of Sophisticated Accounting System in Strategy Management”, The International Journal of Digital Accounting Research, vol. 4, n. 8: 125-144. http://dx.doi.org/10.4192/1577-8517-v4_5

NICOLAU, A.I.; BHATTACHARYA, S. (2006): "Organizational performance effects of ERP systems usage: The impact of post implementation change”, International Journal of 
Accounting Information Systems, vol.7, n1: 18-35. http://dx.doi.org/10.1016/j.accinf.2 $\underline{005.12 .002}$

NIETO, M.J.; FERNANDEZ, Z. (2006): "The role of information technology in business strategy of small and medium enterprises", Journal of International Entrepreneurs, vol.3: 251-262.http://dx.doi.org/10.1007/s10843-006-7854-Z

OECD (2000): Perspectives économiques de l'OECD: "Quels sont les facteurs qui soustendent la croissance dans les différents pays de 1 'OECD?" June n. 67 vol. 2000-1.

PÉREZ ESTÉBANEZ, R.; URQUÍA GRANDE, E.; MUÑOZ COLOMINA, C.I. (2010): "Information Technology implementation for continuous improvement: Empirical evidence in Spanish SME's", International Journal of Accounting and Information Management, vol. 18, n.1: 39-57. http://dx.doi.org/10.1108/18347641011023270

POWELL, T.C.; DENT-MICALLEF, A. (1997): “Information Technology as Competitive Advantage: The role of human, business and technology resources", Strategic Management Journal, vol. 18, n.5: 375-405. http://dx.doi.org/10.1002/(SICI)10970266(199705)18:5<375::AID-SMJ876>3.3.CO;2-Z

RAI, A.; PATNAYAKUNI, R.; PATNAYAKUNI, N. (1996): "Refocusing where and how IT value is realized: An empirical investigation", Omega International Journal of Management Science, vol. 24, n. 4: 399-412. http://dx.doi.org/10.1016/03050483(96)00009-6

RAVICHANDRAN, T.; LERTWONGSATIEN, C. (2005): "Effect of Information Systems, Resources and Capabilities on Firm Performance: A resource based perspective", Journal of Management Information Systems, vol. 21: 237-276.

SANTAMARÍA, L.; NÚÑEZ, M.; GAGO, S. (2010): "The role played by interdependences in ERP implementations: an empirical analysis of critical factors that minimize elapsed time", Information \& Management, http://dx.doi.org/10.1016/j.im.2 $\underline{009.10 .004}$

SANTHANAM, R.; HARTONO, E. (2003): "Issues in linking Information Technology capability to firm performance”, MIS Quaterly, vol. 27, n.1: 125-153.

SCAPENS, R.W.; JAZAYERI, M. (2003): "ERP Systems and Management Accounting change: Opportunities or Impacts? A research note", European Accounting Review, vol. 12, n.1: 201-233. http://dx.doi.org/10.1080/0963818031000087907 
SCAPENS, R.; JAZAYERI, M.; SCAPENS, J. (1998): "SAP: integrated Information Systems and the implications for Management Accountants", Management Accounting Research, vol. 76, n. 8: 46-48.

TAM, K. Y. (1998): “The Impact of Information Technology Investments on Firm Performance and Evaluation: Evidence from Newly Industrialized Economies", Information System Research, vol. 9, n. 1: 85-98. http://dx.doi.org/10.1287/isre.9.1.85 TANABE, K.; WATANBE, C. (2005): "Sources of small and medium enterprises excellent business performance in a service oriented economy", Journal of Services Research, vol. 5, n. 1: 5-20.

VAN DE VEN A.H.; DRAZIN, R. (1985): “The concept of fit in contingency theory”, Resources Organizational Behaviour, vol. 7: 65-333.

VERHEES, J.H.; MEULENBERG, M.T.G. (2004): "Market orientation, Innovativeness, product innovation and Performance in Small Firms", Journal of Small Business Management, vol. 42, n. 2: 134-154. http://dx.doi.org/10.1111/j.1540-627X.2004.00102.x

WAH, L. (2000): “Give ERP a chance”, Management Review, vol. 89, n. 3, pp. 20-24. 


\section{Appendix A. Survey items used in this study}

\begin{tabular}{|l|l|}
\hline TRADE NAME & \\
\hline PERSON INTERVIEWED & \\
\hline POST & \\
\hline FIRM'S LEGAL STATUS & \\
\hline WEB PAGE & \\
\hline E-MAIL & \\
\hline YEAR FOUNDED & \\
\hline NUMBER OF PARTNERS & \\
\hline ACTIVITY & \\
\hline COMPANY REGISTRATION NUMBER & \\
\hline
\end{tabular}

\section{INFORMATION TECHNOLOGIES}

1. Does AIS play an important role in planning the firm's strategies?

2. Does your firm use any AIS for its financial and economic management?

3. What shortcomings do you find in the AIS you use?

4. Do you use the same computerized accounting program for financial, cost and management accounting?

5. How long have you been doing your accounting with a computer program?

6. Does computerized accounting AIS allow you to manage your cash position with banks?

7. Does AIS allow you to manage your fiscal affairs with Government bodies?

8. Do you think that the organization and administration in your firm have improved since using AIS?

\section{NEW INFORMATION TECHNOLOGIES}

9. Are you familiar with new technologies such as ERP, CRM and XML (Extensible Markup Language)?

10. If the answer is "yes", would you be interested in using this free language to keep your accounts? 